\title{
One year results of anti-VEGF treatment in pigment epithelial detachment secondary to macular degeneration
}

\author{
Resultados após um ano de tratamento anti-VEGF para o descolamento do epitélio pigmentado secundário \\ à degeneração macular
}

Harun Yüksel ${ }^{1}$, Fatıh M. Türkcü ${ }^{1}$, Alparslan Şahin ${ }^{1}$, Muhammed Şahin ${ }^{1}$, Yasin ÇInar $^{1}$, Abdullah K. Cingü ${ }^{1}$, Şeyhmus ArI ${ }^{1}$, İhsan Çaça $^{2}$

\begin{abstract}
Purpose: Pigment epithelial detachment (PED) may be seen in all stages of agerelated macular degeneration (ARMD) and may lead to poor prognosis. In this study, we retrospectively examined the effect of anti-VEGF treatments in ARMD patients with vascularized PED.

Methods: Medical records of 15 patients with PED secondary to ARMD were reviewed retrospectively. The diagnosis of PED was made with fundoscopy, fundus fluorescein angiography and optical coherence tomography. Patients were treated with intravitreal ranibizumab or/and bevacizumab and followed up for a minimum of one year. PED height and best corrected visual acuity (BCVA) was obtained before the first intravitreal anti-VEGF injection and again at the $1^{\text {st }}, 3^{\text {rd }}$ $6^{\text {th }}$ and $12^{\text {th }}$ month after the injection.

Results: The mean baseline BCVA was $0.71 \pm 0.48$ logarithm of the minimal angle of resolution (logMAR) unit and the mean baseline PED height was $361 \pm 153 \mu$. The mean injection count per eye was $3.9 \pm 2.9$. There was a significant reduce in mean PED height $(247 \pm 177 \mu$ ) also in 2 eyes PED completely resolved at the end of the follow up period. The mean BCVA at $12^{\text {th }}$ month $(0,69 \pm 0,37)$ were not different from the baseline record.

Conclusions: This retrospective case series showed that intravitreal anti-VEGF therapy preserved vision and reduced PED height in PED patients in a one-year follow-up period.

Keywords: Vascular endothelial growth factor A/antagonists \& Inhibitors; Retinal pigment epithelium/pathology; Retinal detachment; Macular degeneration/drug therapy; Aged
\end{abstract}

\section{RESUMO}

Objetivo: O descolamento do epitélio pigmentado (DEP) pode ser observado em todas as fases da degeneração macular relacionada com a idade (ARMD) e pode propiciar um mau prognóstico. Neste estudo, analisamos retrospectivamente o efeito dos tratamentos anti-VEGF em pacientes com DMRI e DEP vascularizado.

Métodos: Foram revisados prontuários de 15 pacientes com DEP secundário à DMRI. O diagnóstico do DEP foi feito por meio de fundoscopia, angiofluoresceínografia e tomografia de coerência óptica. Os pacientes foram tratados com injeção intravitrea de ranibizumab elou bevacizumab e acompanhados por um período mínimo de um ano. A altura do DEP e a melhor acuidade visual corrigida (AVCC) foi obtida antes e no primeiro, terceiro, sexto e 12을 após a primeira injeção.

Resultados: A média inicial da AVCC foi de 0,71 $\pm 0,48$ (logaritmo do ângulo mínimo de resolução unidade - logMAR) e a média inicial da altura do DEP foi $361 \pm 153 \mu$. A contagem média de injeções por olho foi de 3,9 2,9. Houve uma significativa redução na altura média do PED $(247 \pm 177 \mu)$ e, em dois olhos, o DEP estava completamente resolvido ao final do período de acompanhamento. A acuidade visual média aos 12 meses $(0,69 \pm 0,37)$ não foi diferente da inicial.

Conclusões: Esta série de casos retrospectiva mostrou que a injeção intravítrea de terapia anti-VEGF preservou a visão e a reduziu a altura do DEP em pacientes com DMRI por um período de seguimento de um ano.

Descritores: Fator A de crescimento do endotélio vascular/antagonistas einibidores; Epitélio pigmentado da retina/patologia; Descolamento retiniano; Degeneração macular/quimioterapia; Idoso

\section{INTRODUCTION}

Age-related macular degeneration (ARMD) is a very common cause of vision loss especially in elderly patients living in developed countries ${ }^{(1)}$. ARMD is caused by the accumulation of drusen in the macula, which is the most important part of the retina, and this process ends in serious irreversible visual impairment. Pigment epithelial detachment (PED) may be seen in all stages of ARMD and may lead to poor prognosis because of retina pigment epithelial (RPE) tears, submacular haemorrhage and, finally, disciform scars ${ }^{(2,3)}$. ANCHOR and MARINA studies showed that the vascular endothelial growth factor inhibitor (anti-VEGF), ranibizumab, was effective in the treatment of neovascular ARMD and repeated injections improved or preserved visual acuity $(V A)^{(4,5)}$. However, these large studies did not provide specific information about ARMD patients with PED. In this study, we retrospectively examined the effect of anti-VEGF treatments in ARMD patients with vascularized PED.

\section{METHODS}

This retrospective study was performed in the Department of Ophthalmology at the University of Dicle School of Medicine. The study was approved by the local ethics committee at Dicle University. The medical records of patients with ARMD were reviewed and abstracted between January 2008 and December 2012. The demographic and clinical characteristics of the patients were recorded.

The diagnosis of PED was made with fundoscopy, fundus fluorescein angiography (FA) and optical coherence tomography (OCT) (Stratus, Carl Zeiss Meditec, Dublin, CA $)^{(6,7)}$
Funding: No specific financial support was available for this study. Disclosure of potential conflicts of interest: H.Yüksel, None; F.M.Türcü, None; A.Şahin, None; M.Şahin, None; Y.Çinar, None; A.K.Cingü, None; Ş.Ari, None; I.Çaça, None.

Correspondence address: Harun Yüksel. Dicle Üniversitesi Tıp Fakültesi, Sur/Diyarbakır, Turkey E-mail: harunyuksellI@gmail.com 
In this study, the patients were treated with ranibizumab (Lucentis; Genetech Inc., South San Francisco, CA, USA) or/and bevacizumab (Avastin, Genentech, South San Francisco, CA, USA) and followed up for a minimum of one year. Baseline best corrected visual acuity (BCVA) was obtained before the first intravitreal anti-VEGF injection (V0) and again at the $1^{\text {st }}(\mathrm{V} 1), 3^{\text {rd }}(\mathrm{V} 3), 6^{\text {th }}(\mathrm{V} 6)$ and $12^{\text {th }}(\mathrm{V} 12)$ months after the injection, using the Snellen chart. The treatment modalities used on the patients were also recorded. BCVA was converted to a logarithm of the minimal angle of resolution (logMAR units) for analysis. PED heights were measured during the same visits and noted as PED0, PED1, PED3, PED6 and PED12. PED height was measured from the scanned image using the Proportional Process Report Software in the OCT device (Carl Zeiss Meditec, Dublin, CA), using the method described by Chan et al. ${ }^{(8)}$ (Figure 1). The following exclusion criteria were used: intravitreal triamcinolone (IVTA) injection, photodynamic therapy (PDT), laser photocoagulaton, glaucoma, associated retinal disease, cataract surgery and loss to follow-up.

Results are presented as mean \pm standard deviation (Range). Friedman and Wilcoxon tests were used for statistic analysis of changes in PED height and BCVA. A p-value less than 0.05 was considered statistically significant.

\section{RESULTS}

The medical records of 324 patients were evaluated between January 2008 and December 2012. Fifteen patients were eligible for the study (9 males). The mean age of the patients was $70.9 \pm 5.5$ (61-77) years. Nine of 15 eyes also had intraretinal fluid and four of these nine eyes had also RPE tears. The mean injection count per eye was $3.9 \pm$ $2.9(1-9)$. Twelve patients received only ranibizumab $(n=6)$ or bevacizumab $(n=6)$ and three patients received both treatments. Three of the patients with RPE tears received ranibizumab and another three received bevacizumab.

In the group, the mean V0 was $0.71 \pm 0.48$ logMAR units and the mean PED0 was $361 \pm 153 \mu$. In follow-up visits there was no statistically significant decrease or increase in the mean BCVA (Figure 2). The mean PED3 and PED12 were lower than the baseline PED height $(p=0.003$, $p=0.009$, respectively, Table 1). At the end of the follow-up period, PED completely resolved only in two patients. Neither systemic nor local adverse effects, like uveitis, cataract formation, glaucoma or endophthalmitis, were observed throughout the follow-up period.

\section{DISCUSSION}

It is very difficult to treat patients with ARMD that is also accompanied by PED. The eyes of these patients often have poor prognosis. The pathogenesis of PED in ARMD is explained by age-related changes in Bruch's membrane. In elderly patients, Bruch's membrane thickens due to the accumulation of lipids and abnormal materials. This accumulation results in reduced hydraulic conductivity of the Bruch's membrane-choroid complex, which leads to a decreased capacity for fluid exchange between the choroidal and retinal pigment epithelial compartments ${ }^{(9-11)}$

Anti-VEGF drugs are thought to be effective in treating PED because they reduce vascular RPE permeability. Bevacizumab and ranibizumab have been efficacious for treating various types of retinal vascular diseases. Intravitreal injection of those drugs was shown to be effective in diabetic and veno-occlusive macular edema and $\operatorname{ARMD}^{(5,12,13)}$

In our study, we investigated the BCVA and PED height of patients with pigment epithelial detachments due to ARMD, who were treated with anti-VEGF agents over the course of one year. An average $3.9 \pm 2.9$ (1-9) injections were performed on patients. Repeated injections of ranibizumab and bevacizumab provided a stable BCVA and reduced PED height, despite the fact that PED was not completely resolved in most of patients at the end of one year.

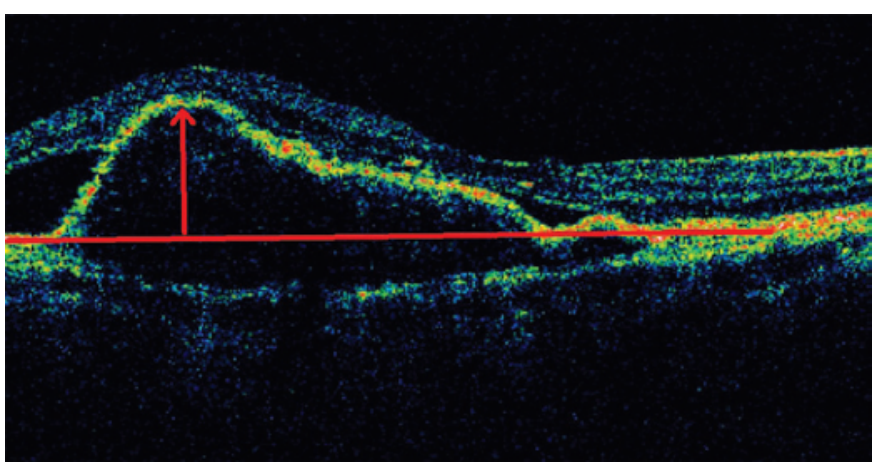

Figure 1. Measurement of pigment epithelial detachment height according to Chan et al. $\operatorname{method}^{(8)}$.

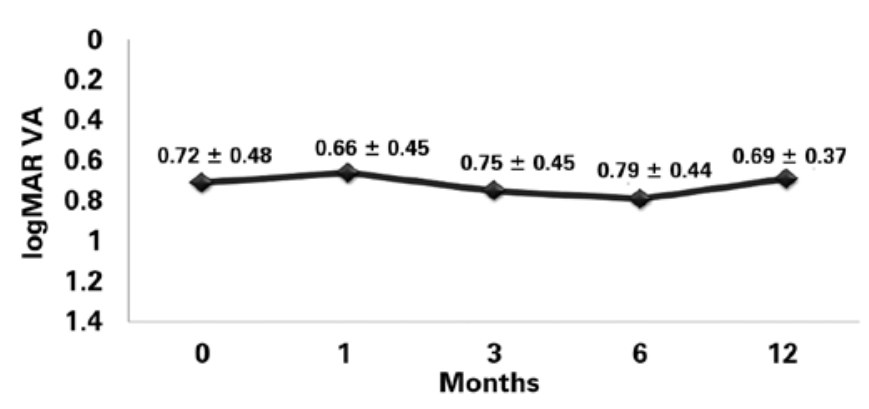

Figure 2. Best corrected visual acuity of patients during follow up visits.

Table 1. Mean macular thickness changes of patients during follow up period

\begin{tabular}{|c|c|c|c|c|c|}
\hline & $\begin{array}{c}\text { Prior to } \\
\text { treatment }\end{array}$ & $1^{\text {st }}$ month & $3^{r d}$ month & $6^{\text {th }}$ month & $12^{\text {th }}$ month \\
\hline $\begin{array}{l}\text { Mean PED } \\
\text { height }\end{array}$ & $361 \pm 153^{a, b}$ & $273 \pm 223$ & $241 \pm 175$ & $270 \pm 207$ & $247 \pm 177$ \\
\hline
\end{tabular}

Many treatments, such as laser photocoagulation and PDT have been used to treat PED that is associated with ARMD. In PDT studies, it has been reported that the VA of patients did not increase and that, in some cases, the patient's VA decreased due to the development of RPE tears, depending on the treatment or the natural course of the disease ${ }^{(14,15)}$. Consequently, on the basis of the association between PED and inflammation, IVTA treatment was added to the PDT. However, that treatment resulted in complications, such as glaucoma and cataracts.

Lommatzsch et al. reported that anti-VEGF agents are the most effective treatment for PED. In their study, they found that anti-VEGF agents were more effective in the treatment of PED due to ARMD than triamcinolone acetonide combined PDT therapy ${ }^{(16)}$. Similar to our study, Chen et al. reported stable or increased vision in PED patients, secondary to ARMD, when treated with intravitreal bevacizumab in an average follow-up period of 30 weeks, despite the continuation of PED ${ }^{(17)}$. However Ritter et al. reported that reduction of PED height was significant at the $6^{\text {th }}$ month mark, but it was not maintained for one year in PED patients treated with anti-VEGF(18). 
The lack of vision increase was thought to be the result of a loss of function in the photoreceptors due to the presence of long-term RPE detachment and RPE tears in some of the patients. RPE tears, which were seen in four $(27 \%)$ of our cases, are one of the most important factors affecting VA in patients with PED. RPE tears either appear at the time of admission or occur after the applied treatment modalities. The incidence of RPE tears in PED patients secondary to ARMD is reported in $40 \%$ of patients treated with PDT and in $26 \%$ of patients treated with anti-VEGF(19).

In the literature, some publications reported a worsening of VA due to the occurrence of an RPE tear after the anti-VEGF injection. Other studies reported no change ${ }^{(20)}$. However, long-term follow-up of these patients is required and when deciding on the course of treatment to use, possible complications should be considered.

This study has some limitations. The number of patients included in the study was not satisfactory because of the one year follow-up period and the retreatment indications were not standardized because of the retrospective study design. Indocyanin angiography could not performed to patients. Furthermore, some of the patients had previously been treated with anti-VEGF drugs. Despite these limitations, this retrospective case series showed that intravitreal anti-VEGF therapy preserved vision and reduced PED height in PED patients in a one-year follow-up period. It is important to note, however, that PED is still difficult to treat and the use of anti-VEGF drugs was not entirely adequate in completely resolving PED in ARMD patients. We need prospective large-scale studies on this subject.

\section{REFERENCES}

1. Congdon NG, Friedman DS, Lietman T. Important causes of visual impairment in the world today. JAMA. 2003;290(15):2057-60.

2. Casswell AG, Kohen D, Bird AC. Retinal pigment epithelial detachments in the elderly: classification and outcome. Br J Ophthalmol. 1985;69(6):397-403.

3. Cukras C, Agrón E, Klein ML, Ferris FL 3rd, Chew EY, Gensler G, Wong WT; Age-Related Eye Disease Study Research Group. Natural history of drusenoid pigment epithelial detachment in age-related macular degeneration: Age-Related Eye Disease Study Report №. 28. Ophthalmology. 2010;117(3):489-99.

4. Brown DM, Kaiser PK, Michels M, Soubrane G, Heier JS, Kim RY, Sy JP, Schneider S: ANCHOR Study Group. Ranibizumab versus verteporfin for neovascular age-related macular degeneration. N Engl J Med. 2006;355(14):1432-44.

5. Rosenfeld PJ, Brown DM, Heier JS, Boyer DS, Kaiser PK, Chung CY, Kim RY; MARINA Study Group. Ranibizumab for neovascular age-related macular degeneration. N Eng
J Med. 2006;355(14):1419-31. Comment in N Engl J Med. 2006;355(14):1493-5. N Engl J Med. 2006; 355(14):1409-12. N Engl J Med. 2007; 356(7):748-9; author reply 749-50. N Engl J Med. 2007; 356(7):747-8; author reply 749-50.

6. Sato T, lida T, Hagimura N, Kishi S. Correlation of optical coherence tomography with angiography in retinal pigment epithelial detachment associated with age-related macular degeneration. Retina. 2004;24(6):910-4. Comment in Retina. 2007;27(9):1316-8; author reply 1318-9.

7. Giovannini A, Amato G, Mariotti C, Scassellati-Sforzolini B. Optical coherence tomography in the assessment of retinal pigment epithelial tear. Retina. 2000;20(1):37-40.

8. Chan CK, Abraham P, Meyer CH, Kokame GT, Kaiser PK, Rauser ME, et al. Optical coherence tomography-measured pigment epithelial detachment height as a predictor for retinal pigment epithelial tears associated with intravitreal bevacizumab injections. Retina. 2010;30(2):203-11.

9. Moore DJ, Hussain AA, Marshall J. Age-related variation in the hydraulic conductivity of Bruch's membrane. Invest Ophthalmol Vis Sci. 1995;36(7):1290-7.

10. Bird AC. Doyne Lecture. Pathogenesis of retinal pigment epithelial detachment in the elderly; the relevance of Bruch's membrane change. Eye (Lond). 1991;5(Pt 1):1-12.

11. Wasmuth S. [Pathogenetic concepts for pigment epithelial detachment in exudative AMD]. Ophthalmologe. 2010;107(12):1109-14. German.

12. Do DV, Nguyen QD, Khwaja AA, Channa R, Sepah YJ, Sophie R, Hafiz G, Campochiaro PA; READ-2 Study Group. Ranibizumab for edema of the macula in diabetes study: 3-year outcomes and the need for prolonged frequent treatment. JAMA Ophthalmol. 2013;131(2):139-45.

13. Epstein DL, Algvere PV, von Wendt G, Seregard S, Kvanta A. Benefit from bevacizumab for macular edema in central retinal vein occlusion: twelve-month results of a prospective, randomized study. Ophthalmology. 2012;119(12):2587-91.

14. Axer-Siegel R, Ehrlich R, Avisar I, Kramer M, Rosenblatt I, Priel E, et al. Combined photodynamic therapy and intravitreal triamcinolone acetonide injection for neovascular age-related macular degeneration with pigment epithelium detachment. Ophthalmic Surg Lasers Imaging. 2006;37(6):455-61.

15. Ladas ID, Kotsolis Al, Rouvas AA, Brouzas D, Moschos MM. Efficacy of photodynamic therapy in the management of occult choroidal neovascularization associated with serous pigment epithelium detachment. Ophthalmologica. 2007;221(5):313-9.

16. Lommatzsch A, Heimes B, Gutfleisch M, Spital G, Zeimer M, Pauleikhoff D. Serous pigment epithelial detachment in age-related macular degeneration: comparison of different treatments. Eye (Lond). 2009;23(12):2163-8.

17. Chen E, Kaiser RS, Vander JF. Intravitreal bevacizumab for refractory pigment epithelial detachment with occult choroidal neovascularization in age-related macular degeneration. Retina. 2007;27(4):445-50.

18. Ritter M, Bolz M, Sacu S, Deák GG, Kiss C, Pruente C, et al. Effect of intravitreal ranibizumab in avascular pigment epithelial detachment. Eye (Lond). 2010;24(6):962-8.

19. Introini U, Torres Gimeno A, Scotti F, Setaccioli M, Giatsidis S, Bandello F. Vascularized retinal pigment epithelial detachment in age-related macular degeneration: treatment and RPE tear incidence. Graefes Arch Clin Exp Ophthalmol. 2012;250(9):1283-92.

20. Coco RM, Sanabria MR, Hernandez AG, Fernández Muñoz M. Retinal pigment epithelium tears in age-related macular degeneration treated with antiangiogenic drugs: a controlled study with long follow-up. Ophthalmologica. 2012;228(2):78-83. 